\title{
POWER SHIFTING AND THE CHALLENGES OF PRESIDENTIAL SYSTEM IN INDONESIA (1945-2019)
}

\author{
Muhammad Naufal, Kamal Muntaha Ahmad, Dara Purnama \\ Padjadjaran University \\ MuhammadI7I46@mail.unpad.ac.id \\ KamalI700I@mail.unpad.ac.id \\ Dara17002@mail.unpad.ac.id
}

\begin{abstract}
The dynamics of government system in Indonesia has a long way road since Indonesia secure their independence in 1945. Acco rding to Indonesia constitution, Indonesia adhere the presidential system. Yet, in practice the government system in Indonesia seems more like a Parliamentary system. During the period of 1945-1959, the presidential system in Indonesia doesn't have any places to operate, entered the guided democracy era, the presidential system obtain its first place. Seeing that, the president success to obtain their power and became a dictator, after Sukarno was remove from the office, Indonesia entered the "new order" regime. This regime just like guided democracy era, the President became center of the power because president was choosed by the parliament and most the fellow comes from the party government. After reformasi in 1998, the presidential system has their own challenges. Considering, the multyparty system felt is not compatible with the presidential system. Hence, as long as Indonesia established, the presidential system in Indonesia has their own dynamic and challenges. Every regime has their own dynamic and challenges. This article aims to provide a study to strengthen the presidential system and using a qualitative approach based on a comprehensive literature review.
\end{abstract}

Keywords: Presidential system, Democracy, Indonesia Government.

Received 4 February 2021 Accepted 23 July 2021

\section{INTRODUCTION}

Indonesia was build upon a great notion and a great dialectics of our founding fathers thoughts. Among so many subject of debate, the contention regarding the government system is one of the most interesting debate to talk about as far as today. The government system in Indonesia has shifted in many times in order to search and build a strong framework of government.

The scope of this article would be examine the historical cross the implementation of presidential system in Indonesia started from the early post independence, yet, just a few the discuss approximately this era. Seeing that Indonesia in this era was adhere to the parliamentary system. Then in the course of Indonesia until now the presidential system is combined with a multi-party system. The presidential system itself in writing is contained in the Constitution of 1945 in contrast to the multi-party system that is not explicitly mentioned. Multiparty system is an inevitability considering Indonesia is a country that has a very complex level of plurality.

In addition, with plurality in the Indonesian nation, the presidential system is the best choice in maintaining the stability of government. The NKRI narrative also emphasizes that 
diversity in Indonesia must also be united with something so as not to happen undesirable things. But unfortunately the implementation of this combination of presidential and multiparty systems empirically often causes problems. This can be seen from various government regimes.

\section{LITERATURE REVIEW}

Presidential system in Indonesia is attracting many scholars to discuss. One of them is Saldi Isra. He wrote a book, sistem pemerintahan Indonesia Pergulatan Ketatanegaraan Menuju Sistem Pemerintahan Presidensial [1] (Isra,2019). This book tries to retrace the root of the presidential system in Indonesia. Especially the power shifting and the challenges in every era. Furthermore, after reformasi, MPR were trying to purifying the presidential system in Indonesia through three steps. First, the president is elected by the people, second, limiting the periode of the president, and third clear up the definition of president and vice president impeachment [1] (Isra,2019:149-184).

In another view, Scott Mainwaring in his article, Presidentialism, Multipartism, and Democracy: The Difficult Combination [2] discusses how the mismatch between these two system. Especially those all occurred in most of Latin America.The presidential system is adhere by many countries with plural conditions, because one of the goals of presidentialism is to create stability in democracy. But Mainwaring concluded there was ultimately a mismatch between the presidential and multiparty systems. Especially with the polarization of party ideology that makes it difficult for the President to form a solid and solid coalition.

A journey of the presidential system in Indonesia was also written by Diana Fawzi in Sistem Presidensial Indonesia dari Soekarno ke Jokowi [3](Fawzia et al., 2018). As we know that Indonesia has undergone several changes in the system of government, in this book Diana tries to examine how the complexities and challenges that occur in the application of the presidential system in Indonesia in various regimes from the era of Soekarno leadership to Jokowi.

\section{RESEARCH METHODS}

This research adopts a qualitative approach based on a comprehensive literature review. In doing so, the author tries to review, critique, corelate, and synthesize all related literature in order to generate new perspectives or ideas. A total of 11 literature was used in this study. Keywords used to focus the search are 'Presidential system', 'multi party', 'Democracy', 'Indonesia Government'.

\section{FINDINGS AND DISCUSSION}

Broadly speaking, Indonesia adhere to the presidential system. It was begin from the enactment of the Indonesia constitution UUD 1945 in August 18 on 1945. Eventhough, the form of the government system written in the constitution is draw an attention from the law scholars, e.g. Sri Soemantri have a certain views the UUD 1945, adhere to the mix government system which, it is a mix between the presidential and parliamentary system [1] (Isra,2019:5).

On the other hand, Saldi Isra [1] argues that the government system in Indonesia as an adolescent state era was unique. Furthermore he is disagree with Sri Soemantri argument. Owing to UUD 1945 which isn't regulating the matter of election. Where as, the election as well as presidential or parliamentary system is the key. Hence, he argues that the form of 
government system at that time was unique. Yet, when we try to see the condition at that time, admittedly, the constitution was made in a rush. Because, the condition forced it.

On the other hand, Indonesia once undertake the parliamentary system during 19501959. Although, the parliamentary system was operated from 14 November 1945 which marked by the appointment of Sutan Sjahrir as a prime minister.

\section{Guided Democracy (1959-1966): President authoritarian and the dead of democracy}

After operated the parliamentary system as long as 14 years. The unstabilty of the government comes out as a main notion to Indonesia for not operating the parliamentary system no more. The cause of the parliamentary system was fell it is because there was a huge political spectrum gap amongst the party [4]. On the other hand, Sukarno accused the konstituante whose selected on 1955 had failed to contrive a new constitution [4] (2019:134).

Those all began when Sukarno enacted the emergency law, the July 5th president decree. Which is contain the dissolution of konstituante and the house of representative whose elected on the 1955 election, and put back the UUD 1945 as a constitution. After all, the MPRS also enacted TAP NO III/MPRS/1963 about the levitation of Sukarno as an Indonesia president for life [5] (2020:189).

Simultaneously, in that moment, Sukarno became a dictator, moreover, Hatta was criticized the steps those Sukarno takes through his pamphlet which is called "Demokrasi kita". Furthermore, Hatta and Prawoto Mangkusasmito argues, the president decree was inconstitutional and such a coup by Sukarno. Conceptionally, in the presidential system, the organ can't dissolve each other. But in this era, Sukarno was dissolving the house of representatives and establishing a new $D P R$, which called $D P R-G R$ and consist of "Sukarno yes-man". On the other hand, the supreme court officiate as president advisor which has same level as a minister [1] (2019:114). Consequently, when the parliamentary was appointed by the president and the judiciary is just only an advisor of president, at that time, that was no check and balances no more in the government. Hence, executive heavy was occur in this era. Moreover, there is no check and balances amongst the government institution [6] (2019:vi).

After 6 years dominating the regime, Sukarno was falling from the office. Main issues of fall of the Sukarno regime was a G30S occurrence and the high inflation amount occur during that time was made a social movement rising in almost every province in Indonesia which named, "Gerakan Tritura". The MPRS was nullified the constitute of the appointment of Sukarno as Indonesia president for life. Furthermore, MPRS enacted Tap MPRS No XXXIII/1967, which consist of the removal of president Sukarno from the office, at a time appointment of Suharto as a mandatory of MPRS.

\section{New Order Regime (1966-1998): Presidential or Parliamentary System?}

After the fall of the Sukarno regime in 1966, Indonesia entered the new regime, new order, under Suharto leadership. This era was established approximately 32 years until the reform in 1998. Just like before, this regime was not democratic one such as, the guided democracy, but the differences is the guided democracy is inconstitutional yet, the new order is a constitutional one [4].

During this regime, the government agenda is only to consolidate the power of the to strengthen the president position as a core of the state [1]. The president's power in this era was very vigorous. Indeed, we can say the president became a core power in the government. 
Interesting to discuss, because According to UUD 1945 article 6 before the amendment certainly gave $M P R$ to elect the president and the vice president. Consequently, the parliament wasn,t only a 'yes-man' of the president. Because, on the other hand, Suharto was elected as a president for 32 years wasn't separated from the role of the $M P R$ whose maintain his throne. In this context, we can conclude, the construction of the executive, in casu the president was a final resultante of the political negotiation at once, as a face of the majority of the parliament, In casu MPR. Considering, the concentration of scramble power through an election was in the parliament. Not, the president.

Furthermore, if we try to see the political context of the new order regime, Suharto power was consolidated through three main actors, ABRI, Golkar, and Burreaucracy [4].

Golkar hegemonies with a support from $A B R I$ in the parliament was a key for Suharto to maintain his throne. As we can see in table 1 below which clearly shows the composition of the parliament was dominated by Golkar and ABRI. On the other hand, $A B R I$ whose a places in the parliament isn't a member of the parliament whose elected by the people. But, through a process of appointment. We can see this as a 'free cake' for ABRI who was helping Suharto to maintain his power. [1] (2019:119).

Table 1. Map of MPR Power Factions in the New Order Era

\begin{tabular}{|l|l|l|l|l|l|l|}
\hline Faction & $\begin{array}{l}1972- \\
1977\end{array}$ & $\begin{array}{l}1977- \\
1982\end{array}$ & $\begin{array}{l}1982- \\
1987\end{array}$ & $\begin{array}{l}1987- \\
1992\end{array}$ & $\begin{array}{l}1992- \\
1997\end{array}$ & $\begin{array}{l}1997- \\
1999\end{array}$ \\
\hline ABRI & 230 & 230 & 230 & 151 & 155 & 113 \\
\hline $\begin{array}{l}\text { Karya } \\
\text { Pembangunan }\end{array}$ & 392 & 381 & 395 & 548 & 240 & 588 \\
\hline PDI & 42 & 39 & 32 & 61 & 84 & 16 \\
\hline PPP & 126 & 131 & 123 & 93 & 93 & 134 \\
\hline $\begin{array}{l}\text { Utusan } \\
\text { Daerah }\end{array}$ & 130 & 139 & 140 & 147 & 149 & 149 \\
\hline Jumlah & 920 & 920 & 920 & 1000 & 1000 & 1000 \\
\hline
\end{tabular}

(Source: www.mpr.go.id)

Hence, during the new order regime, was occurred the concentration of power and responsibility upon the president [1] (2019:117). Although, the president was elected by MPR. In 1998, the monetary crisis occurred in asia was reaching its climax. Each day, the people pretension for Suharto to resign as a president of Indonesia was strengthen. After that, in May 21 1998, Suharto was put back the throne of the president and continued by his vice president, Habibie as a successor. 


\section{Reformasi I (1999-2003): The Strong Parliament and Purification of Presidential System}

When president Soeharto step down in May 1998 it marked the beginning of a new period in Indonesian history that called Reformation. And at the moment vice president B.J Habibie took over the presidency. During his leadership, Habibie and parliament made so many policy in various aspect such as amendment Undang-Undang Dasar 1945 to restrict the president's term of office and also give freedom to form political parties. These policies are certainly a turning point in the democratic process in Indonesia.

As a result of the freedom of party formation issued by Habibie, number of political parties increase significantly as many as 48 political parties be participants in the 1999 elections. The number of new political parties at that time illustrated that the multiparty system in Indonesia has taken place. Although since the first elections in 1955 Indonesia adhere to the multi-party system, but in the era of the new order there is a dominance of party power by Golkar as a government party. This implying the occurrence of a presidential election process that was considered pseudo, because the majority of lawmakers that came from Golkar choose Soeharto as president 7 times terms of office over 32 years.

Table 2. Result Vote acquired based on 1999 election

\begin{tabular}{|l|l|l|l|}
\hline No & Party & Number of votes $(\%)$ & Seats in parliament \\
\hline 1 & PDIP & 30,8 & 154 \\
\hline 2 & Golkar & 24 & 120 \\
\hline 3 & Partai Persatuan Pembangunan & 11,8 & 59 \\
\hline 4 & Partai Kebangkitan Bangsa & 10,2 & 51 \\
\hline 5 & TNI/Polri & 7,6 & 38 \\
\hline 6 & Partai Amanat Nasional & 7 & 33 \\
\hline 7 & Partai Bulan Bintang & 2,6 & 13 \\
\hline 8 & Partai Keadilam & 1,2 & 6 \\
\hline 9 & Partai Keadilan dan Kesatuan & 1,2 & 6 \\
\hline 10 & Partai Demokrasi Kasih Bangsa & 0,6 & 3 \\
\hline
\end{tabular}

(Sources : https://ditpolkom.bappenas.go.id)

Based on the results of the 1999 elections, PDI-P be the party who has the most vote followed by Golkar, PKB, PPP and PAN. However, at that time there was an anomaly in the general election, because PDI-P as the party that got the highest vote in the election predicted that Megawati would be the president but it was precisely at that time Abdurrahman Wahid or better known as Wahid who was elected president carried by the central axis form Amin Rais.

During wahid's leadership, there were also amendments of Undang-Undang Dasar 1945. One of the points of change is to firmer enforcement of the presidential system in Indonesia. Because at that time the presidential system was not yet enforceable which was indicated by 
the concept of the Majelis Permusyawarat Rakyat Indonesia (MPR). In the other hand, there is also an amendment to Article 6 which states that the president is directly elected by the people. These changes aim to create a much stronger presidential system.

After being elected, Wahid formed a National Unity cabinet that received support from PKB, Golkar, PDIP, PPP, PAN, PBB, and Partai Keadilan. As a logical consequence of the support provided by these parties, Wahid formed his cabinet based on the "recommendations" of the leaders of the parties. Of the 34 seats in the cabinet $67.6 \%$ were filled by representatives of his supporting party. The compromise that occurred between Wahid and his supporting party in the future caused problems, especially when the removal of Hamzah Haz as Minister of State for Investment which was then also followed by the removal of Jusuf Kalla and Laksamana Sukardi, causing the coalition to break up. The relationship between the executive and the legislative became inharmonious and the coalition reversed course in the middle of the road and be initiator to carrying out the impeachment of Wahid [7] (Natsir,2015).

This condition indicates that at that time there was political instability during wahid's reign. The combination of the presidential system and the multiparty system does not support the creation of democratic stability [1] (2019:204). In the context of Wahid's government, even if wahid had the support of the central axis coalition with the most votes in parliament but in the practice of organizing the government is not necessarily able to run the government steadily. This loose and dynamic coalition can actually cause problems for the government.

After Wahid's impeachment, the President's office was replaced by Megawati. During Megawati's leadership, the relationship between the exclusivity and parliament was relatively more conducive. Although the parlemen at that time had tried to sue Megawati through the proposed use of interpellation rights in several cases including the case of the release of Sipadan and Ligitan islands from Indonesia. However, Megawati can establish communication with legislative to ease the various lawsuits. Stable relationship between the executive and the legislature is impact from the impeachment of Wahid previously, so that legislative and executive "playing" in the safe zone to secure his position and this is what is the weakness in implementing the presidential system combined with the multiparty system.

However from Habibie to Megawati's leadership, the 1945 Constitution has undergone 4 amendments (1999-2002) and the purification of the presidential system of government is carried out in the form of: (1) Changing the process of presidential/vice presidential elections from elections with a representative system to direct elections, (2) Limit the period of the term of office of the president and vice president, (3) Clarify the mechanism of impeachment of the president / vice president, (4) Prohibition for the president to dissolve the House of Representatives, (5) Update or rearrange MPR, (6) Institutionalizing the testing mechanism for the purification of the presidential system of government [7] (Natsir,2015).

ased on the runtutan events of the government from the leadership of Habibie to Megawati it appears that the parliament enjoys the power of what experts call the "parliamentary dictatorship"[3] (Fawzia et al,2018:257). Although post-reform has spawned a purification of the presidential system, there are difficulties in implementing the mandate of the constitution when combined with a multiparty political system. Coalitions are very difficult to avoid in a presidential system combined with multiparty. Moreover, the coalition that was built was identified as very vulnerable and loose because of the character of the parties in the coalition is undisciplined, opportunistic, and pragmatic [8] (Agil,2015). The situation has left 
the president in a dilemma, between compromising parliament or sticking to a presidential principle that is not yet fully solid.

\section{Reformasi II (2004-2019): Seeking a Strong Presidential System}

Summarized in merdeka.com, senior journalist named Derek Manangka who successfully interviewed Megawati during her meeting in Teuku Umar. Derek said that Mega had received a report by Gen. (Purn) AM Hendropriyono, who at that time who was holding the post as a Head of the Badan Intelijen Negara), said there were a signs that he was creating a new political party. The party that will be used as a political vehicle in the 2004 elections. Even though in the end SBY avoided admitting it, this actually happened in the 2004 elections. SBY won the 2004 Pilpres after passing 2 rounds of elections with a $60.62 \%$ for the SBY-JK and $39.38 \%$ for the Mega-Muzadi as a final result.

The results of the Legislative Election were an important consideration in the history of presidentialism in Indonesia. SBY-JK was promoted by Partai Demokrat, Partai Bulan Bintang, and Partai Keadilan and Persatuan Indonesia to became a minority parties in the parliament. Demokrat Party, as the main bearing party, just only obtained around $7.45 \%$ of the parliamentary seats. On the other hand, PDI-P as an opposition who was a rival of SBY in the election, can obtained until $18.58 \%$ seats in the parliament.

As a minority, SBY and Demokrat party must try hard to run the government in the future. The low number of seats in the parliament can be a threaten to the stability of the government because of the lack of direct support for the policies taken by the executive when they need an approval from the parliament.

The path that SBY took during his tenure as a president with a minority parties in the parliament was forced him to build a coalition with other parties. Such as, Golkar as a $2^{\text {nd }}$ winner of the parliament election. The political journey undertaken by SBY is a different matter from what has happened recently. The construction of the parliamentary coalition building was actually built by SBY after his victory in the 2004 presidential election. In contrast to what has happened now that the Coalition was formed long before the announcement of the election winner. So that the bonds of solidarity in the coalition are a bit fragile and can be doubted [1] (2019: 215).

The Golongan Karya party, which eventually became a coalition in the SBY-JK administration for the 2004-2009 period, often "harassed" SBY by refusing to acknowledge several Golkar cadres who were placed in the cabinet. Then with the addition of Golkar cadres in the cabinet, Golkar still does not fully support government policies in the Legislative House [1] (2019: 215).

The shakiness in SBY's political journey as president did not only stop in his first term, eventhough, in his second term with Boediono also experienced a lot of pressure in the coalition. The Bail Out of Century Bank case became SBY's biggest threat in his administration. 
Table 3. Parliament Election Result 2009

\begin{tabular}{|c|l|l|c|}
\hline No. & \multicolumn{1}{|c|}{ Fraksi } & \multicolumn{1}{|c|}{ Political Party } & Amount \\
\hline 1. & F-PD & Partai Demokrat & 148 \\
\hline 2. & F-PG & Partai Golongan Karya & 106 \\
\hline 3. & F-PKS & Partai Keadilan Sejahtera & 57 \\
\hline 4. & F-PAN & Partai Amanat Nasional & 46 \\
\hline 5. & F-PPP & Partai Persatuan Pembangunan & 38 \\
\hline 6. & F-PKB & Partai Kebangkitan Bangsa & 28 \\
\hline 7. & FPDI-P & Partai Demokrasi Indonesia Perjuangan & 26 \\
\hline 8. & F-GERINDRA & Partai Gerakan Indonesia Raya & 17 \\
\hline 9. & F-HANURA & Partai Hati Nurani Rakyat & $\mathbf{5 6 0}$ \\
\hline & & Total Amount & 94 \\
\hline
\end{tabular}

Source: http://www.dpr.go.id

The Special Committee for the Century bailout was formed by the DPR 40 days after SBY-Boediono assigned as a President of Indonesia in 2009-2014. The Special Committee for the Century bailout was initiated by $9 D P R$ members or known as a "nine team". The nine people, namely: Maruar Sirait (PDI-P), Bambang Soesatyo (Golkar), Ahmad Muzani (Gerindra), Andi Rahmat (PKS), Mukhamad Misbakhun (PKS), Chandra Tirta Wijaya (PAN), Kurdi Mukhtar (PPP), Lili Wahid (PKB), and Akbar Faisal (Hanura). Six of them are members of coalition parties as a supporting parties of SBY government in the Parliament. After all, we can conclude, when six out of nine the initiators were part of SBY government supporting parties, the biggest question was whether the coalition that existed at that time was really strong? Because the Century bailout policy was the first major policy taken by the SBY administration in his second term as President of Indonesia [1] (Isra, 2019: 218).

One of the challenges of the Indonesian Presidential is to build the stability of the government which tends to hold the power of the presidential itself hostage. To maintain the stability of the government, of course a president as the center of the executive circle must be able to embrace the influence of the legislature as well. This contradicts the ideals of Montesquieu's trias politica, which argues that it is important to have a separation of powers in government.

It seems that by trying to make the two important power holders, the checks and balances in power are unclear. In the Jokowi regime from 2014-2019, the 34 assistants in the 
cabinet there were 27 positions filled by members of political parties, counting with several changes. In this note, it can be interpreted that the existence of political parties in a coalition becomes a dilemma for the presidential system itself. Coalition political parties can be a smooth tool for government policy but on the other hand, it can be a threat to executive and presidential power as well.

An effective presidential system is determined by several variables, namely: (1) The formation of a cabinet and the pattern of president-political party relations. As well as with a firm and strong presidential capability so that the formation of a cabinet is based on the prerogative rights of the president. (2) The practice of checks and balances runs effectively within the corridors of democracy and the strong and firm personality of the President. (3) Impeachment of the President can only be done for legal reasons. (4) The composition of the cabinet is filled by a majority of professionals (zaken cabinet). (5) The Ministers loyalty is fully to the President (6) The main tasks and functions of the President and Vice President are clearly regulated by taking into account the principles of presidentialism [9] (Saraswati, 2012).

Hanta Yudha [1] (2019: 223) argued that the presidential system and the support of the multiparty system resulted in two qualifications; namely the compromise of external politics (legislative) and internal political compromise (executive). Regarding external compromises that weaken the strength of the presidential system, among others: (1) the high political compromise of the president in the formulation / reshuffling of the cabinet with coalition supporting parties, (2) the fragility of coalition ties of political parties supporting the coalition, (3) excessive parliamentary control of the government; (4) the shadow of impeachment by parliament.

Meanwhile, internal compromises that are considered to weaken the presidential system are: (1) the reduction of the president's prerogative rights in determining and arranging the cabinet, (2) the cabinet is filled by party people, so that it is difficult for professionals (zaken cabinet) to be realized; (3) the dualism of the loyalty of ministers from political parties because the appointment process tends to consider the recommendations of political parties that are members of the coalition [1] (2019: 223).

The fragility and weakness of the presidential system with the support of the multi-party system also has other discontinuities. As Scott Mainwaring argues, First, a multiparty-based presidential system produces parliamentary debates that are too fragmented and sharp so that one day it can result in paralysis in government. Second, multiparty systems generate ideological polarization rather than being dual-party so that they often cause problems when linked to presidential systems. Third, the combination of building coalitions between parties in democratic presidentialism has implications for damaging democratic stability [2] (Mainwaring, 1993).

As we have mention above, Mainwaring argues that when the multiparty system meets the presidential system. Both, they aren't compatible each other, However, in Indonesia political system, these two are adhering and the existence of a multi-party system in Indonesia lately is colored by the catch all party so that ideological polarization just like Mainwaring argues, does not becoming a problem for Indonesian presidentialism in this era. But if we try to look back during 1945-1966 the gap of parties ideological spectrum was became a serious problem. The biggest problem with the Indonesian presidential system is the powers that exist within the sphere of government become authoritarian. It is occurring when the ruling parties even in the executive or parliament is just the same. This means that what is occuring now, 
however, is the Indonesian presidential system forcing to form a coalitions. If the presidential system has to choose to become a minority party or a majority party in the parliament, being a minority is the best choice in government so that checks and balances and the separation of powers in government run well [1] (2019:3) .

\section{CONCLUSION}

Presidential sysyem in Indonesia has faced so many challenges and power shifting. During the period of 1945-1959, The presidential system in Indonesia doesn't have any place to operate. Entered the guided democracy era, the presidential system obtain its first place. Seeing that, the president success to obtain their power and became a dictator. After Soekarno was remove from the office, Indonesia entered the new regime well known as "new order". This regime, just like democracy era the president became center of the power. President was choosed by the parliament and parliament is one of the power for president to maintain its 32 years regime

After Suharto's regime fall down, Habibie as his successor tried to fix the situation. One of the step his do is by amending the Constitution of 1945 concerning restrictions on the term of office of the president which is then continued by wahid and Megawati. But unfortunately in the course of reform efforts carried out to strengthen the presidential system is still not able to run optimally, this can not be separated from the influence of the multiparty system in Indonesia. The combination of presidential and multi-party systems often creates government instability.

The phenomenon that occurred in Indonesia is very interesting to be studied further, related to how the long journey of the Indonesian nation in realizing the ideals of the nation. Elections in the reform era have given little idea to understand the condition of the presidential system in Indonesia. The multiparty system in Indonesia is not actually running properly with the ideology of each party. Instead it became catch-allparty. Finally, the phenomenon in Indonesia is not as bad as described by Scott Mainwaring towards the unitedness of these two systems. However, the breakup of the coalition and the hostage-taking of the President's power remain a major issue of the Presidentialism and Multipartaism.

As written belows, the table would summarize dynamic of presidential system in Indonesia:

Tabel 4. Map of Power Shifting and The Challenges

\begin{tabular}{|l|l|l|}
\hline \multicolumn{1}{|c|}{ Regime } & \multicolumn{1}{|c|}{ Core Power } & \multicolumn{1}{c|}{ Challenges } \\
\hline Guided Democracy & Soekarno & $\begin{array}{l}\text { - There was a lack of check and } \\
\text { balances } \\
- \text { Concentration power upon the } \\
\text { president }\end{array}$ \\
\hline New Order & Soeharto, Golkar and ABRI & $\begin{array}{l}\text { - With a majority support from the } \\
\text { parliament the president was } \\
\text { succeed to maintain his throne as } \\
\text { long as 32 years }\end{array}$ \\
\hline
\end{tabular}




\begin{tabular}{|l|l|l|}
\hline Reformasi I & $\begin{array}{l}\text { B.J Habibie, Abdurrahman } \\
\text { Wahid, Megawati Soekarno } \\
\text { Putri, And Amien Rais }\end{array}$ & $\begin{array}{l}\text { - Unconsolidated political forces } \\
\text { after the collapse of the new order } \\
\text { so as to create polarization that } \\
\text { occurs between political parties } \\
\text { and there strengthening power of } \\
\text { parliament } \\
\text { The relationship between the } \\
\text { executive and legislative loose } \\
\text { actually caused problems of } \\
\text { government }\end{array}$ \\
\hline Reformasi II & Parties Coalition & $\begin{array}{l}\text { President Trapped by the } \\
\text { coalition parties }\end{array}$ \\
\hline
\end{tabular}

\section{REFERENCES}

[1] Isra, Saldi. Sistem Pemerintahan Indonesia : Pergulatan Ketatanegaraan Menuju Sistem Pemerintahan Presidensial. Rajagrafindo Persada. Depok. (2019).

[2] Mainwaring, S, Presidentialism, Multipartism, and Democracy : The Difficult Combination', Comparative Political Studies, 26(2). (1993) 198-228

[3] Fawzi, Diana. Noor, Firman. Bhakti, I.N. Gayatri, I.H. Nurdin, Nurliah. Bahar, Safruddin.Siregar, S.N. Jati, W.R. Sistem Presidensial Indonesia dari Soekarno ke Jokowi. (2018) 287-305.

[4] Mahfud, Moh. Politik Hukum di Indonesia. Rajawali Press. Depok. (2019)

[5] Isra, Saldi. Lembaga Negara Konsep, Sejarah, Wewenang dan Dinamika Konstitusional. Rajagrafindo Persada. Depok (2020)

[6] Romli, Lili. Sistem Presidensial Indonesia : Dinamika, Probelematik dan Penguatan Kelembagaan. Setara Press. Malang (2019)

[7] Natsir, Ashar.Impelementasi Sistem Pemerintahan Presidensil pada Masa Pemerintahan Abdurrahman Wahid. (2015). http://repositori.uinalauddin.ac.id/10597/1/implementasi\%20sistem\%20pemerintahan\%20presidensi1\%20pad a\%20masa.pdf

[8] Agil, Oktaryal .Penguatan Sistem Presidensial Melalui Penyederhanaan Jumlah Partai Politik Di Indonesia. (2015)

[9] Saraswati, R, 'Desain Sistem Pemerintahan Presidensial yang Efektif'. (2012) 137-143 